\title{
MULTIPLE SARCOMIAT. HISTORY OF A CASE SHOWING MODIFICATION AND AMELIORATION OF SYMPTOMIS UNDER LARGE DOSES OF ARSENIC.
}

BY SA3rel Sherwell, M.D.

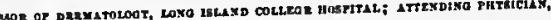

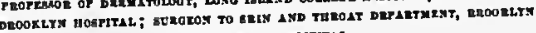
IT AXD EA nostraL.

True following nre the chief points of interest, in giviag the suhjoined history, or rather histories, of this interestiag case.

1. The very large dosage of arsenical solutions.

2. The extrema tolerance of them hy the individual.

3. Tbeir well-marked beneficial effect upon the growth nnd the individual.

4. The complete or nlmost complete suhsidence of the tumors nt various times wbile the treatment was under way, nnd their ready recurrence oa suspension of same.

5. The relative ohstinncy of the growths situated on the neck nnd liend to treatment.

6. The evident delny of the ultimate lethal issue, in spite of the recalcitrancy of the pnticnt.

7. Tbnt the treatment instituted was originnl in cbarncter, the nuthor nt the time of its commencement not being acquainted with the writings nnd experiments of $K o ̈ b n e r$ nnd others in the snme direction.

The patient, Mr. G. S. H., nged thirty-nine years, nntive of United States, medium height, fnirly well-built nnd nourished, of somewhat ncrvous and nnxious expression, was first seen hy me nt my office toward the end of Fehrunry, 1888. He hnd at the time a large indolently ulcerating tumor situated on the posterior portion of the left thigh, the lower portion involving thc upper pnrt of the poplitenl spacc; be claimed that it hod its origin in irritation caused by an unesen and hroken high stool, upon which he had heen nccustomed to sit at his duties ns $\mathrm{n}$ clerk in nn office; it first commenced as an indurated lump with inflnmed border, then began to ulcerate, nhout four months previous to his first visit, and had become as I now snw it. He dated his earliest noted symptoms bnck to nhout n year from the date of visit. Recognizing nn interesting nnd prohahly maligannt trouble, I treated him $n$ few days with placehos nnd cleansing applications. The New York Dcrmatologicnl Society meeting of February, 1888, occurring a short time after, I presented him there for diagnosis and discusgion on his ease, which is reported hriefly. in the April number of thnt year, in the Journal for Culnneous and Venereal Diseases, under the heading of "The Society's Proceedings:" It was regarded as mnlignant hy most of those present, my own opinion heing that it was sarcomatous.

Ahlation was recommended hy almost all. He would not suhmit to this, nud refused even to bnve a small piece taken out for microscopical examination. 
The tumor grew rapidly larger, while the patient still deprecated any operative measures, although strongly urged, until, the indications of its malignity becoming evident eren to himself, he at last yielded, and on April 15, 1888, nt his own house, I removed the whole of the tumor and surroundings dowa to the fascia, hy $n$ nearly eircular in. cision, the wound measuring four and a quarter inches ia dinmeter, the tumor itself nt the time measuring three and $n$ quarter inches in dinmeter, so thnt the zone of slightly involved tissue was well included; the wound was cauterized with chromic ncid nnd nllowed to heal hy granulntion. Portions of the tumor extending from the free margin to the eentre were exnmined by Drs. G. T. Elliott, A. R. Rohinson, the President of the Brooklyn Microscopical Society, nnd myself, nll coming to the same conclusion, that it was undoubtedly sarcomntous.

The progress of healing of the wound being necessarily slow, he was allowed to leave for the eountry (New Hanpshire, his home) at the end of Mny; he remnined awny a little over n month, returning at the end of that time with still $n$ smnll open sore. During this month's ahsence nnother smull huttun-shnped nnd quickly ulcerating tumor had appeared on the right thigh just below Poupart's ligament, which he absolutely refused to lct me excise or take other radicnl meang to remove. He still remnined innttentive as regards visits, nlthough he said he would try any medieiue, nnd begged for it. Later on, in the course of three months, $\mathrm{a}$ large numher of otber tumors nppeared in various regions of the body; on both nntes, sides of chest, over the shoulder, on the arms, were quite lnrge ones, nll of which developed more rapidly thnn the first in the femoral region, with which they wcre nniform in general appearance a ad mode of progressioa, save that there was greatly inereased rapidity of development everywhere.

I bnd given no internnl treatment to speak of up to this time, except for a short time at the end of Fehrunry nnd heginning of Mareh, when I tried $\mathrm{m}$ netive eourse of mixed treatment which seemcd to hasten uleeration, nnd was eonsequently stopped.

The snme requests, as at first, for instant opcration for nhlntion of the growths met with the same fight for delny, so that it was not until he became hopeless of nny improvement without thnt coursc, thnt bc finally consented, nnd on October 7,1888 , he cntered Brooklyn Hospitul, as my prisnte pnticnt, I being then on service, for a course of entirely radical treatment.

I operated on him on thnt dny, he being under anzsthesia ahout two hours. I removed the tumor in the femoral region (it measured two inches in diameter) hy excision; six other lnrge ones, none being less in dinmeter than $n$ silver dollnr; nnd n number of smnller ones, ahout thirty in all, I extirpnted partly hy excision, partly by raclage with shnrp dermal curette; cauterizing nll with chromic acid nround edges of wounds, nnd thereafter using bandages nnd dressings of simple cerate. I had previously resolved to test the effect of nrsenic in full doses, nnd in $\mathbf{n}$ cumulntive way, hnviug $\mathbf{n}$ distinct belief thnt it would favorahly affect his condition, but must own that I was surprised nt the evident heneficial effect in a relntively short time. I put bim, then, nhout thirty-sis hours after the operation, on a mixture of four parts of Fowler's to one of Donornn's solutions, to commenee with eight-drop doses of the mixture four times a dny, adding dnily at least one drop to each dose, sometimes more, until I had bim taking twenty-six to thirty 
drops four times a day; ahout that time he would usually, and sometimes before he reached that limit, show an amount of constitutional reaction, which though not as extreme as might he thought, would be sufficiently marked to show the danger limit, and the stomach would give out a little, so that it would hecome imperative to suspend the remedy for awhile, and give the stomach rest for a day or two, never longer, heginaing immediately again with ahout ten-drop doses.

Irany of the small tumors, half-pea sized, or even larger, which I had not curetted, disappeared in a very few days, not more than a fortnight or at most three weeks after instituting this constitutional treatment; all iafiltration of the edges and areola dying away where there had been iafiltration arouad other tumors, and on the former sites of thege small tumors an atrophied spot could be felt, such as occurs in morphosa or in scleroderma after suhsideace of the acute lesion. He did steadily well, hecame able to attend to business ia some measure, and in December 1888, I first took him to my friend, Dr. A. R. Rohinson, who had previously been in consultation with me just hefore his reception iato Brooklyn Hospital, for a thorough examiantioa, and subsequently took him to the Decemher Session of the New York Dermatological Society, when I placed him in evideace as n valuahle, not to say wonderful, illustration of what arsenic can do in modifying this form of kakoplastic embryoaal fihrous tissue. He then, with my permission, took cars for his native place to pass Christmas and Newr Year, with precise orders how to take his remedies, whea to leave them off, and with most distiact and solemn promises on his part to keep me vell posted as to his progress, etc. I heard thereafter once or twice from him nt disconnected times; he evidently fell under iafuences that were not town in which he lived, who used his hest efforts to keep him in linc, hut failed; so that from this time I may be said to have lost control of the case.

Whea I next heard of him he was in the hands of Dr. John B. Wheeler, of the Collcge and Mary Fletcher Hospital, Burlington, Vt., who kiadly furaished the following complementary history :

"Whea Mr. H. first camc uader my care, Fehruary 15, 1889, be was covercd with the sarcomatous growths with which you are familiar. They varied in size from oaeeeighth inch to two and a balf inches in diameter. He was in a coaditioa of extreme exhaustion, excessively hypersesthetic, so that he could hardly hear a touch without screaming, sleeping with grent difficulty, and almost deroid of appetite. Under these circumstances I thought it hest not to begin the arsenic treatment which he said had had a very good effect on the growths hut a very had one on him, and I therefore put him on quinine, stimulants, and morphiae, with the intention of huildiag him up and of removiag the growths as fast as I could. This treatment was contiaued until May 1st. Duriag this time I operated on him four times, at intervals of two or three. weeks, and removed in all one hundred and seventy tunors. They were cut out with scissors and the raw surfaces thoroughly huraed with the Paquelin cautery. Careful antisepsis was observed, hut after granulation began the raw surfaces were dressed with balsam of Peru. Ificroscopical examination of the growths removed showed $\varepsilon$ structure fairly typical of sarcoma. Recurrence took place faster than it was possible to operate, and the only advantage afforded hy operation was 
that the growths were removed when they were small. No recurrence, hovever, ever took place in a cicatrix, except on the scalp, where the skin surrounding the growth 3 had become mueh more inhiltrated than elsewhere. Everywhere else the wounds granulated well and cicatrized quite promptly, the new growths all appearing in the sound skin.

“On. May I, 1889, as the sarcomna were multiplying rapidly aud the patient had got into a very fair condition of general health, I began to give him the same mirture which I believe you used, one part of Donovan's solution and four parts of Fowler's. The dose was at first ten drops, $t$. $i$. d., hut as soon as I found he hore that without trouble, the dose was increased one drop every day. He stood this very well until doses from eighteen to twenty-fire drops were reachel (sometimes I could get him up to twenty-five, sometimes not above eighteen) whin his appetite disnppeared, his eyelids swelled, and he becane nausented, and very nervous and hyperesthetic. The dose was then cut down to ten drops, when lie would hecome all right again, whereupon the dose was again gradually increased to the limit of tolerance. He took his arsenic in this way as long $n$ s he was under ny care, raising aud lowering the dose according to indications, and nlso took from one and a half to six ounces of whiskey, and from $\mathrm{g}$ gr. to $1 \mathrm{gr}$. of morphine daily most of the time.

" In ahout four weeks it hecamc evident that no nell growths were appearing, and that those which had grown since the last operation (some thirty in numher, some of them one inch in diameter and badly ulcerated) were less nngry looking and wcre diminishing in size. By the end of June, not the fainlest sign of a malignant grouth was left ${ }^{2}$ on the man (except the cicatrices showing where the growths had becn), saving some half-dozen on the face and scalp, which for some reason (great vascularity of skin of those parts ?) seemed to resist the arsenic with uncommon obstinacy.

"By the 20th of July, the patient had hecome so thoroughly poisoned with arsenic, swelled eyelids, losg of appetite, strength, nerrousness, hypernesthesia, and despondency (no diarrhen) that I hecame alurmed and stopped his arsenic for ten days. at the end of this time his general heal th had improved greatly, hut $\mathrm{n}$ dozen new sarcomata had appeared on trunk and extremities.

"The arsenis was resumed .July 30 th, in the same way ns hefore. For ahout a wcek the sarcomata enlarged until some reached one inel in diameter, then they hecame less inflamed and diminished in size. No otbers appeared.

"By August 22d sereral of the growths had disappcared and the remaining ones rere steadily diminisbing. At this time the paticnt became vcry desirous to go to his home in New Hampshire, and as he was in fair condition and apparently able to stand the journey, I con. sented to his departure, which he took on that day. My only news from him since then is n short note written hy his physician the day afier reaching home, which informed me that Mr. H. had stood the journey well."

The exact date of his demise I do not now remember, hut his friends informed me that it was ahout the end of Decemher of that year, it being

1 Eafcrlinel in original. 
due apparently to neglect of remedies, recurrence, and consequeat exhaustion.

In' regard to what I have termed, at the commencement of this paper, the poiats of interest in this case:

First. While there may he records of larger therapeutic doses used than those here givea, the time element also being considered, none such have comc under my notice in my readings. The daily amount of arseaious acid was, as will be noticed, about a graia a day at times. As regards the mixture, which will be semembered as being four parts of Fowler's and oae of Donoran's solutions respectively, I may say that I added the latter solution, not for its specific mercurial effect, hut as an additional and effective ahsorhent or resolvent agent.

No doubt as to correctness of diagnosis is probahle-the high grade of examiners renders that impossible; hut should such douht exist, the balance of the larger tumor is still in alcohol in my possession, and is at the scrvicc of anyonc interested in tbe subject.

Second. The tolcrunce, as was evident, was exceedingly marked, and the very rapid disappearance of toxic symptoms oll cessation of the remedy was peculiarly so; in a couple of days, ordinarily, all such symptoms, gastric or other, would entirely disappear. This, however, I do not think unusual, as a good many patients suffering from psoriasis whom I have treated at some time hy arseuic in the course of their discase, havo shown the same ready disappearance of bad effects.

Thirl. It is now scarcely necessary to say aaything as to the effect upon the individual or the tumors; as to the latter the listory speaks, but as to individual it may he further said that while he was under observation the fairly large doses (not those near the toxic mark) seemed to heaefit and improve nutrition and strength.

Fourth. The subsidence of the tumors ou taking the remedy has niso becu sufficiently dwclt on in the histories, hnt it rould seem important to call attention once more to the fact of their extremely rapid recurrence on disuse of the remedies; this was very marked, and seemed to he very like a problcm in arithmetical progression; the more tumors present, the more rapidly would others develop in other parts, and the more readily would ulceration in the larger ones begin and continue.

Fifth. The relative regional obstiaacy in regard to treatmeat. This was noted hy Dr. Wheeler particularly, and though not so specially noted in $\mathrm{my}$ history, was ohserved hy myself. To particularize: At the time of operation in the hospital, I purposcly left one growth oa the neck, ahore the eollar, in order to better ohserve its conduct while under constitutional treatment: preciscly that one, and one or two others on the scalp, were the slowest to respond, persisting after others had entircly disappeared. I have noted this fact before, and in an article read before the American Dermatological Association, "Remarks on, and 
Queries as to, the Relative Frequeacy of Pathological Changes ia Moles aud other Tumors on the Face and Head," which was published in the Joumal of Cutaneous and Genito-urinary Diseases, January, 1887, I usc the folloning words: "There are many other parts of the body, it would seem, equally or more exposed to these accideats thun the carefully guarded face; as for iastrace the hards, nates, waist, and neck; the two latter from coastant friction of clothiag aad other causes. Holes aad other small tumors are sufficieatly commoa oa all parts of the hody, hut it would nppear by the statistics givea, and by other experieaces of the writer, tbat the ratio of further and destructive pathological activity is much less ia them (that is in all other parts of the hody) than on the hend nad face." Further: "The most rationnl way of solutioa or accouatiag for the frequeacy of these growths oa the site meatioaed is probably tbat it is after all due to the extent, nature, and ahuadance of circulatory nutrition, which must favor hyperplasia in these wellsupplied parts," etc.

Sixth. Delay of lethal effects of the disease I shall not dwell upoa; it was certaialy evident to all having any close coanection with the crse.

Seventh. As has beea stated, though it may resd as a confessiou of carelessaess on his part, the nuthor at the time of inceptioa of constitutionnl treatment was ignorant of the records of recent experiment of others in the same directioa. He had, however, heen long conviaced of the ia hihitire efficieacy of the drug ia other maligaant affections, a otahly epithelioma, aad has been very lately additioaally confirmed ia tbis by many cases, nmong which may he cited a receat aad marked oae of geaital epithelioma; a secoadnry operatioa haviag heea done, followed by a third, to remove immensely involved iaguiual glands aad tissuc. The operatioa was hrilliantly nnd radically performed hy one of New York's leadiag surgeons; hut nll the consulting medical men (nt least five in nunlher, including mysclf) decided it was impossihle, or nlmost so, for recurrence not to rapidly take place, and the patient was hy general serdict given naywhere hetwcea three and six moaths to live. This occurred about a year siace. Arsenical treatmeat, at my suggestioa, has beca since employed. The iadividual is now living and eajoyiag bettcr health npparently thnn for some years previous. This coascrvative result, I believe, has beea largely due to the result of this coastitutioaal treatment.

Dr. H. Kōhner's writiags aad cases came uader my ohscrvatioa some moaths after inccptioa of my trentment, hut siace that had acted so well, I did aot feel like "changing horses while crossing n strenm," and persevered with iateraal medication.

It will he a oted that Dr. Köhner gave his arseaic hypodermatically, which douhtless bas its advaatages, but also its disadvantages, as causing slight wouads and points of irritatioa. 
I do not see why the conjoined treatment, internal and hypodernatic, might not he used with greater heuefit than either alone, or at least so, where rapid results seem necessary.

His papers will be found in the Berliner klin. Wochenschrift, 1883, page 21, under tbe title of "Heilung eines Falles von allgemeinen Sarcomatose der Haut durch suhcutane Arseninjection." Also, in 1886 (ibid., p. 193), there is report of a case shown nt a meeting of the Berlin Medical Society, under the heading "Vorstellung eines Falles von multiplen Hautsarkomen der Extremitäten."

Dr. Funk, of Warsaw, in the Monatshefle f. prakt. Dermatologie, 1889 , viii., page 19 , puhlishes an exhaustive article under the title of "Klinische Studien über Sarkone der Haut," giving histories of cases of his own in wbich be bad followed Köbner's plan of trentment, nnd a general rérumé of the subject and writings thereupon. The article would serve as a bibliograpbical index. He recommends, as does Köbner, the injection of a recent solution of arsenite of soda, as heing on the whole the hest.

As I bave before said, the union of the internal and hypodermatic methods would, however, in my opinion, seem to offer the best future therapy. 